\title{
Gingival-Derived Mesenchymal Stem Cells Protect Against Sepsis and Its Complications [Retraction]
}

\author{
Wang X, Song H, Zhao S, Guan W, Gao Y. Infect Drug Resist. 2021;14:3341-3355
}

The Editor and Publisher of Infection and Drug Resistance wish to retract the published article. Following a request from the authors to replace several images within the article it was found several images from the article appeared to have been duplicated with those from other publications by the same authors. Specifically:

- Figure 5A Sham group appears to have been duplicated with Figure 4B LPS from Wang et al. Sci Rep 11, 17772 (2021) (https://doi.org/10.1038/s41598-021-97101-0).

- Figure 6D Sham group appears to have been duplicated with Figure 5E Con group from Wang et al. Sci Rep 11, 17772 (2021) (https://doi.org/10.1038/s41598-021-97101-0).

- Figure 7A Sham group appears to have been duplicated with Figure 6C Ex group from Wang et al. Sci Rep 11, 17772 (2021) (https://doi.org/10.1038/s41598-021-97101-0).

- Figure 3D Sham $24 \mathrm{~h}$ appears to have been duplicated with Figures 2a and 2c Con group and Ex group, respectively, from Wang et al. Research Gate (2021) (https://doi.org/10.21203/rs.3.rs-289593/v1).

- Figure 4E LPS group appears to have been duplicated with Figure 7b LPS group from Wang et al. Research Gate (2021) (https://doi.org/10.21203/rs.3.rs-289593/v1).

- Figure 5A Sham group appears to have been duplicated with Figure 4c Ex group from Wang et al. Research Gate (2021) (https://doi.org/10.21203/rs.3.rs-289593/v1).

- Figure 7A Sham group appears to have been duplicated with Figure 6c Ex group from Wang et al. Research Gate (2021) (https://doi.org/10.21203/rs.3.rs-289593/v1).

The authors responded to our queries but were unable to provide a satisfactory explanation for the alleged image duplication or provide the original images from the study. This raised concerns over the reliability of the findings reported and the Editor requested for the article to be retracted.

Our decision-making was informed by our policy on publishing ethics and integrity and the COPE guidelines on retraction.

The retracted article will remain online to maintain the scholarly record, but it will be digitally watermarked on each page as "Retracted".

\section{Publish your work in this journal}

Infection and Drug Resistance is an international, peer-reviewed open-access journal that focuses on the optimal treatment of infection (bacterial, fungal and viral) and the development and institution of preventive strategies to minimize the development and spread of resistance. The journal is specifically concerned with the epidemiology of antibiotic resistance and the mechanisms of resistance development and diffusion in both hospitals and the community. The manuscript management system is completely online and includes a very quick and fair peer-review system, which is all easy to use. Visit http://www.dovepress.com/testimonials.php to read real quotes from published authors. 